\title{
Toxicity Assessment of Sediments with Natural Anomalous Concentrations in Heavy Metals by the Use of Bioassay
}

\author{
Francisco Martín, ${ }^{1}$ Marlon Escoto, ${ }^{2}$ Juan Fernández, ${ }^{1}$ Emilia Fernández, ${ }^{1}$ Elena Arco, ${ }^{1}$ \\ Manuel Sierra, ${ }^{1}$ and Carlos Dorronsoro ${ }^{1}$ \\ ${ }^{1}$ Departamento de Edafología y Química Agrícola, Universidad de Granada, Campus Fuentenueva s/n, 18071 Granada, Spain \\ ${ }^{2}$ Departamento de Manejo de Recursos Naturales y Ambiente, Universidad Nacional de Agricultura, P.C. 9, Catacamas, \\ Olancho, Honduras
}

Correspondence should be addressed to Francisco Martín, fjmartin@ugr.es

Received 15 January 2010; Revised 5 April 2010; Accepted 26 May 2010

Academic Editor: Evans M. Nkhalambayausi-Chirwa

Copyright ( $) 2010$ Francisco Martín et al. This is an open access article distributed under the Creative Commons Attribution License, which permits unrestricted use, distribution, and reproduction in any medium, provided the original work is properly cited.

The potential toxicity in riverbed sediments was assessed with a bioassay using the bioluminescent bacteria Vibrio fischeri. The selected area was characterized by the presence of ultramafic rocks (peridotites), and the sediments had high values in Ni, Cr, and Co. For the toxicity bioassay with Vibrio fischeri, water-soluble forms were used. The results indicated that most of the samples had a very low degree of toxicity, with $10 \%$ of reduction in luminescence in relation to the control; meanwhile $25 \%$ of the samples had a moderate degree of toxicity with a reduction in luminescence between 13 and $21 \%$ in relation to the control. The toxicity index correlated significantly with the concentrations of $\mathrm{Ni}$ and $\mathrm{Cr}$ in the water extracts. This toxicity bioassay was proved to be a sensitive and useful tool to detect potential toxicity in solutions, even with anomalous concentrations in heavy metals of natural origin.

\section{Introduction}

Today, in Ecological Risk Assessment (ERA), soil and sediment contamination studies are increasingly important. ERA processes involve several predictive and descriptive phases $[1,2]$ with special emphasis placed on the toxicity characterization of the contaminated media. In this field, many toxicity assays are applied in the study of contaminated soils [3-6], and for ecosystem protection, toxicity bioassays are key to support the regulation framework in the declaration of contaminated soils [7].

Most bioassays applied to contaminated soils and sediments are based on the evaluation of the toxic effect of the solution extracted from the solid phase or by the solid phase itself over a living organism (animals, algae, plants, and bacterial bioassays) [8]. In this way, bacterial bioassays are commonly used because they are quick, cost effective, and reproducible [9]. Particularly, the bioassay using Vibrio fischeri relates the presence of contaminants to the inhibition in light emission from these luminescent bacteria. This test is defined as sensitive and has a high correlation with the response of other toxicity tests [10]; in addition, it has been used in the toxicity assessment of soils contaminated by heavy metals $[11,12]$.

Rivers distribute heavy metals in the ecosystem by mobilizing pollutants and thus spreading the affected area, with potential toxicity risk to aquatic organisms as well as to human health through the food chain. Heavy metals can reach aquatic ecosystems by anthropic activities or by natural processes, and in such circumstances, the contaminants can be distributed as water-soluble species, colloids, suspended forms, or sedimentary phases [13]. According to Jain [14], heavy metal pollution in aquatic ecosystems has received increased scientific attention in the recent years because the contaminants tend to accumulate and progressively raise the toxicity risk to the living organisms [15]. In this sense, many studies have demonstrated that heavy metal concentration in river bed sediments can be good indicators of pollution in hydrological systems [16].

The different forms of heavy metals in the sediments of an aquatic medium determine their bioavailability and toxicity. Thus, the study of the different fractions of the 
elements in sediments is vital, because the total concentrations are not representative of the real degree of the potential contamination. Heavy metals can be bound to or occluded in amorphous materials, adsorbed on clay surfaces or iron/manganese oxyhydroxides, coprecipitated in secondary minerals such as carbonates, sulphates, or oxides, complexed with organic matter, or included in the lattice of primary minerals such as silicates [13]. The fractionation techniques of heavy metals in the river sediments have been used by different authors $[14,17-20]$ to assess the mobility and bioavailability of pollutants in this media.

The Verde River basin is located in the Province of Malaga (southern Spain), and its catchment area receives many streams flowing over peridotitic materials, characterized by high concentrations of $\mathrm{Mn}, \mathrm{Cr}, \mathrm{Co}$, and $\mathrm{Ni}$. In this basin lies La Concepción Reservoir, which contributes with more than $24 \%$ of the drinking water used in the western Costa del Sol (dominated by the city of Marbella), one of the main tourist areas in Spain and in southern Europe. The abovementioned scenario prompted the examination of the riverbed sediments of this area.

In this study, we analyse the concentration in the riverbed sediments of heavy metals, both total as well as watersoluble forms, to characterize the potential mobility of these elements in the Verde River basin. The potential toxicity of heavy metals was studied using bioassay of bioluminescent bacteria in order to assess the potential risk of contamination in the area.

\section{Material and Methods}

Verde River is approximately $36 \mathrm{~km}$ long, originating in the Sierra de Las Nieves mountains (2000 m.a.s.l.) and sharply descending to $400 \mathrm{~m}$ to reach the Mediterranean Sea. This abrupt change in altitude in a short distance involves many different slopes, with the steeper ones predominating $(25 \%-55 \%)$. The lithology is dominated by peridotite and serpentine rocks and with carbonate and metamorphic rocks in lesser proportion (Figure 1). The catchment area is comprised of the main channel of the Verde River and 11 tributaries, including La Concepción reservoir, holding $44,515 \mathrm{hm}^{3} /$ year.

Sediments of the Verde River and main tributaries were collected in the bottom part of each stream (Figure 1). At each sampling point, composite samples were taken by mixing $250 \mathrm{~g}$ of sediments from each corner and center of a square $0.5 \mathrm{~m}$ per side. Samples were taken from the river bed to $0-20 \mathrm{~cm}$ depth. In the laboratory, samples were air dried, and the fine fraction $(<50 \mu \mathrm{m})$ of the sediments $[19,21]$ was used to characterize the main properties for the toxicity bioassay.

The total heavy metals were determined by Inductively Coupled Plasma-Mass Spectrometry (ICP-MS) in a PE SCIEX ELAN-500A spectrophotometer. The analyses were made after acid digestion $\left(\mathrm{HNO}_{3}+\mathrm{HF}\right.$; ratio 2:3) at a high temperature and pressure in a Teflon-lined vessel. The spectrometer was equipped with quartz torch, nickel sampler, and skimmer cones, a cross-flow type pneumatic nebulizer, and a double-pass Scott-type spray chamber.
Instrumental drift was monitored by regularly running standard element solutions between samples. The watersoluble forms were obtained from sediment-water extract in a ratio of $1: 5[22,23]$, and the heavy metals solubilized were also determined by ICP-MS. All ICP-MS standards were prepared from ICP single-element standard solutions (Merck quality) after appropriate dilution with $10 \% \mathrm{HNO}_{3}$. For calibration, two sets of multielement standards containing all the analytes of interest at five concentrations were prepared using rhodium as an internal standard. Procedural blanks for estimating the detection limits $\left(3^{*} \sigma ; n=6\right)$ were $<0.96 \mathrm{ppb}$ for $\mathrm{Mn},<2.73 \mathrm{ppb}$ for $\mathrm{Cr},<0.24 \mathrm{ppb}$ for $\mathrm{Co},<0.42 \mathrm{ppb}$ for $\mathrm{Ni}$, $<0.12 \mathrm{ppb}$ for $\mathrm{Cu},<2.68 \mathrm{ppb}$ for $\mathrm{Zn},<0.21 \mathrm{ppb}$ for $\mathrm{As}$, and $<0.23 \mathrm{ppb}$ for $\mathrm{Pb}$. The analytical precision was better than $\pm 5 \%$ in all cases.

The toxicity bioassay was made with the water extract of the sediment. Prior to the assay, $\mathrm{pH}$ was measured potentiometrically in a $1: 5$ soil: water suspension in a CRISON 501 instrument, and electric conductivity (EC) was measured at $25^{\circ} \mathrm{C}$ in a CRISON 522 instrument. The toxicity bioassay was made with bacterium (Vibrio fischeri), which diminishes its bioluminescence capacity in the presence of toxic elements. The freeze-dried luminescent bacteria (NRLLB-11177) and the reconstitution solution were supplied by AZUR Environmental. The test was performed in a Microtox 500 analyser from Microbics Corporation, according to a modification of Microtox Basic Test for Aqueous Extracts Protocol [24], in which the water-sediment extracts and a control sample (distilled water) were used, with three replicates per sample. The luminescence was measured before the mixture with the extracts $(0 \mathrm{~min})$. The inhibition of bioluminescence was measured at 5 (Inh5) and 15 minutes (Inh15) after the mixture with the extracts of the samples. Afterwards, these measurements were used to calculate two Toxicity Indexes:

(i) normalized Inhibition of luminescence at $5 \mathrm{~min}$ (I5), calculated by:

$$
\mathrm{I} 5=\frac{-\left(\operatorname{Inh} 5_{\text {sample }}-\operatorname{Inh} 5_{\text {control }}\right)}{100-\operatorname{Inh} 5_{\text {control }}},
$$

where Inh $5_{\text {sample }}$ is the percentage of luminescence reduction in the samples at $5 \mathrm{~min}$, and $\operatorname{Inh} 5_{\text {control }}$ is percentage of luminescence reduction of control at 5 min.

(ii) normalized inhibition at $15 \mathrm{~min}$ (I15), calculated by:

$$
\mathrm{I} 15=\frac{-\left(\text { Inh } 15_{\text {sample }}-\text { Inh } 15_{\text {control }}\right)}{100-\text { Inh } 15_{\text {control }}},
$$

where Inh $15_{\text {sample }}$ is the percentage of reduction of the sample at $15 \mathrm{~min}$, and Inh $15_{\text {control }}$ is the percentage of reduction of control at $15 \mathrm{~min}$;

The values of I5 and I15 can range from -1 (maximum toxicity) to $>0$, and the following classes can be established: (a) 0 to -0.25 low, (b) -0.25 to -0.5 moderate, (c) -0.5 to -0.75 high, and (d) -0.75 to -1 very high toxicity. Values $>0$ would indicate stimulation of the luminescence (hormesis). 


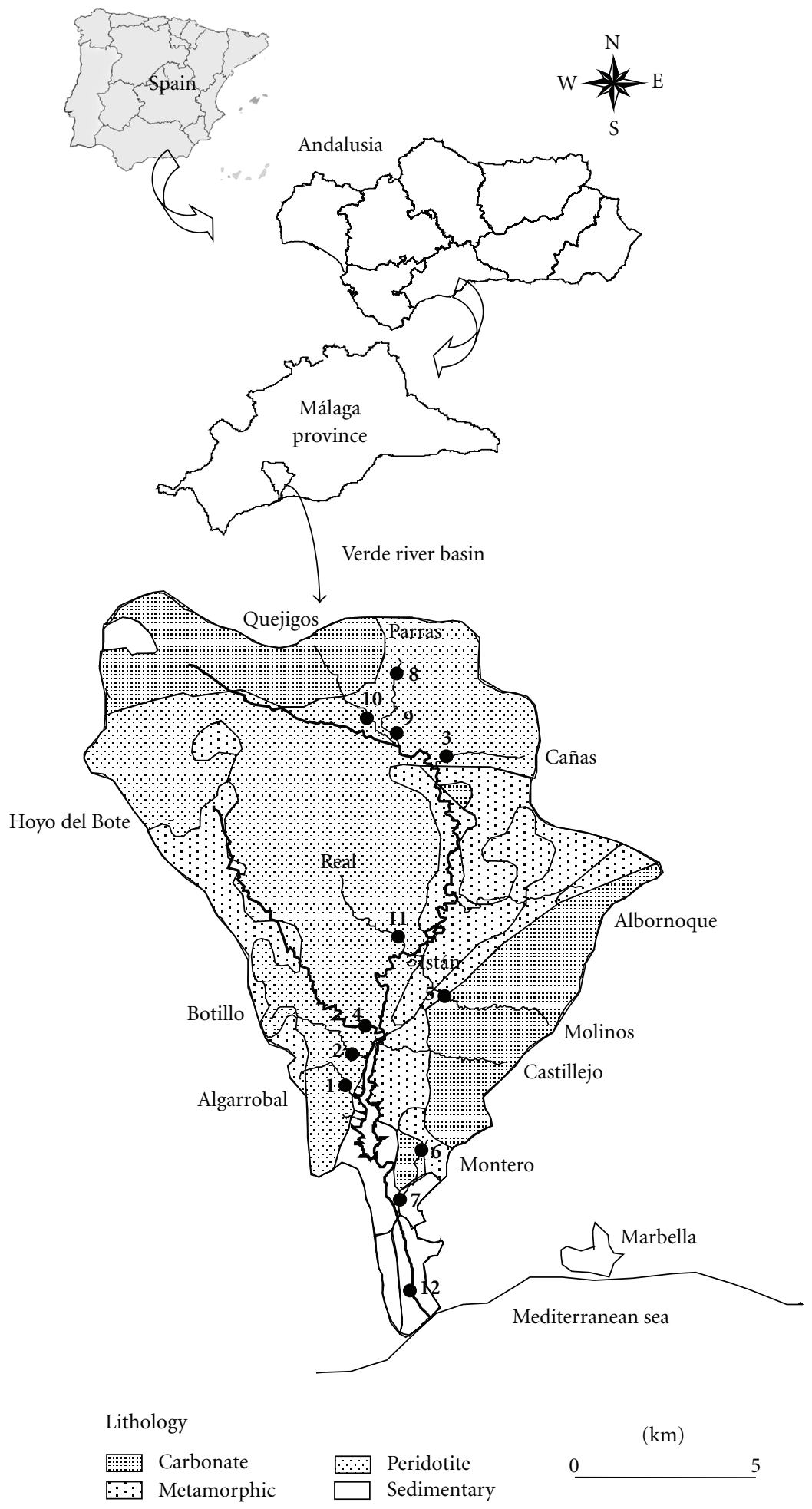

FIGURE 1: Location of the study area, sampling points, and lithological scheme of the River Verde basin.

\section{Results and Discussion}

The total concentrations of heavy metals in the sediments (Table 1) indicate that the peridotite materials have very high concentrations in $\mathrm{Cr}, \mathrm{Ni}, \mathrm{Mn}$, and $\mathrm{Co}$ while in the other materials (carbonate and metamorphic rocks) the values of these elements are low, and the concentrations in $\mathrm{Zn}$ and As are higher than in the peridotite area; the differences in $\mathrm{Pb}$ are not statistically significant between the two types of materials. Therefore, the total concentrations in heavy metals 
TABle 1: Total heavy-metal concentrations $\left(\mathrm{mg} \mathrm{kg}^{-1}\right)$ in sediments from peridotite materials and from other materials in the Verde River basin.

\begin{tabular}{lcc}
\hline & Peridotite & Other materials \\
\hline $\mathrm{Mn}$ & $1244.95 \pm 81.92$ & $708.07 \pm 165.37$ \\
$\mathrm{Cr}$ & $1040.79 \pm 131.15$ & $236.00 \pm 125.62$ \\
$\mathrm{Co}$ & $114.86 \pm 14.21$ & $34.00 \pm 13.49$ \\
$\mathrm{Ni}$ & $1833.26 \pm 232.46$ & $372.78 \pm 273.77$ \\
$\mathrm{Cu}$ & $23.93 \pm 1.45$ & $32.50 \pm 4.09$ \\
$\mathrm{Zn}$ & $69.40 \pm 6.10$ & $166.64 \pm 67.25$ \\
$\mathrm{As}$ & $4.94 \pm 0.80$ & $26.41 \pm 13.30$ \\
$\mathrm{~Pb}$ & $19.43 \pm 4.09$ & $21.75 \pm 6.97$ \\
\hline
\end{tabular}

TABLe 2: Water-soluble heavy-metal concentrations $\left(\mathrm{mg} \mathrm{kg}^{-1}\right)$ in sediments from peridotite and from other materials in the Verde River basin.

\begin{tabular}{lcc}
\hline & Peridotite & Other materials \\
\hline $\mathrm{Mn}$ & $0.497 \pm 0.245$ & $0.280 \pm 0.151$ \\
$\mathrm{Cr}$ & $0.013 \pm 0.004$ & $0.002 \pm 0.001$ \\
$\mathrm{Co}$ & $0.015 \pm 0.006$ & $0.003 \pm 0.001$ \\
$\mathrm{Ni}$ & $0.153 \pm 0.048$ & $0.008 \pm 0.002$ \\
$\mathrm{Cu}$ & $0.009 \pm 0.002$ & $0.008 \pm 0.002$ \\
$\mathrm{Zn}$ & $0.019 \pm 0.006$ & $0.011 \pm 0.006$ \\
$\mathrm{As}$ & $0.005 \pm 0.001$ & $0.004 \pm 0.002$ \\
$\mathrm{~Pb}$ & $0.0004 \pm 0.0003$ & $0.0004 \pm 0.0003$ \\
\hline
\end{tabular}

in the sediments of the Verde River are directly related to the different parent materials present in the area.

The highest heavy-metal concentrations were for $\mathrm{Ni}$ and $\mathrm{Cr}$, with maximum values of $2552 \mathrm{mg} \mathrm{kg}^{-1}$ and $1514 \mathrm{mg} \mathrm{kg}^{-1}$, respectively. According to the geochemical background of the trace elements in soils of Andalusia [25], the sediments of the study area have anomalous values only for $\mathrm{Ni}, \mathrm{Cr}$, and $\mathrm{Co}$ in the peridotite materials, with concentrations exceeding, respectively, 36-, 10-, and 2-fold the reference values for the region. The concentrations of the other elements were within the normal range in all cases.

For the assessment of the potential toxicity of the samples, water extracts of the sediments were obtained to make the toxicity bioassay using luminescent bacteria. The main variables affecting the measurement in the bioassay were $\mathrm{pH}$ and electric conductivity (EC); these properties should be determined to assess their influence in the test results. The water extract of the samples had a $\mathrm{pH}$ value of $8.03 \pm 0.13$, and the mean value of $\mathrm{EC}$ was $1.36 \pm 0.12$. These values are within the recommended range for this toxicity bioassay [26]. The concentration of soluble heavy metals in the water extracts are presented in Table 2. The sediments coming from the peridotite area had significantly higher concentrations in soluble $\mathrm{Ni}, \mathrm{Cr}$, and $\mathrm{Co}$ than the sediments coming from other materials. The other elements analysed had no significant differences in their soluble concentration between the different materials considered.

According to the toxicity bioassay with Vibrio fischeri, most samples showed a decrease in the luminescence in

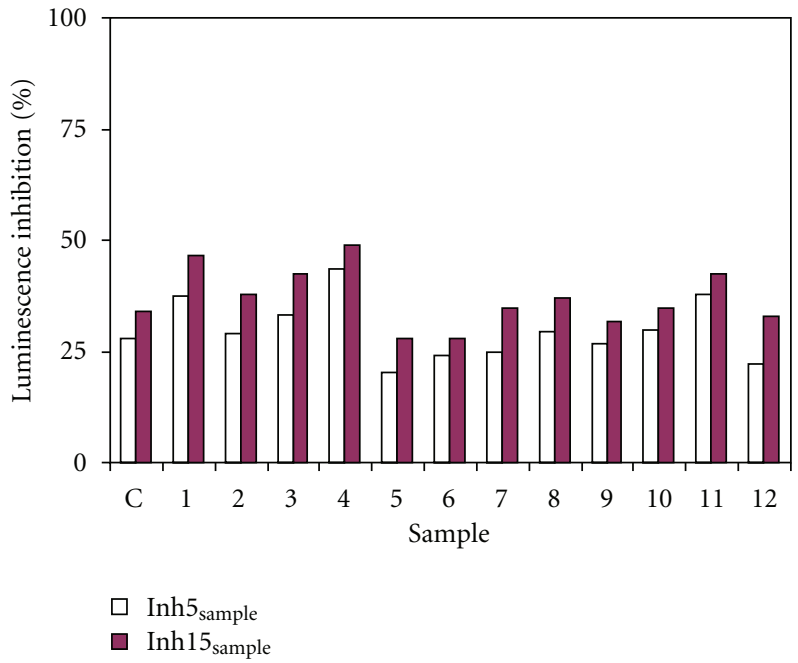

FIGURE 2: Luminescence inhibition (\%) of the water extract in the sediment analysed $(\mathrm{C}=$ control sample).

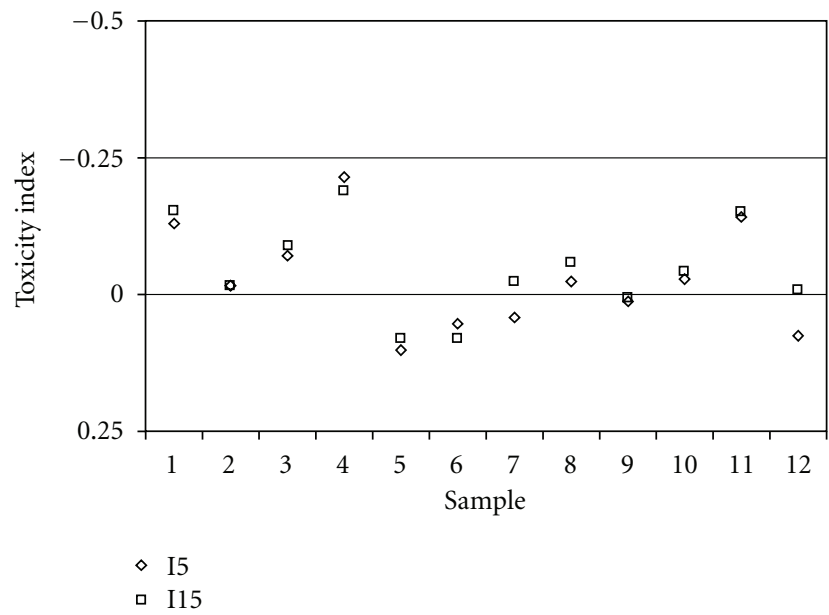

FIgURE 3: Toxicity index of the water extract in the sediment analysed.

relation to the initial value (Figure 2). Because this bacterium is from a marine environment, the control samples (distilled water) had also a luminescence reduction of between 27 and $34 \%$. The water extract of the samples showed a reduction at $5 \mathrm{~min}\left(\mathrm{Inh} 5_{\text {sample }}\right)$ and $15 \mathrm{~min}\left(\mathrm{Inh} 15_{\text {sample }}\right)$ below $50 \%$ in relation to the initial value in all cases although these values were normalized to calculate the inhibition in relation to the control. The lower inhibition of luminescence was found in the sediments belonging to the nonperidotite area (samples 5,6 , and 7) and in sample 12, which received a mixture of sediment both from the peridotite materials as well as from the metamorphic carbonate area.

The water extracts of the sediments had a very low toxicity index in most cases (Figure 3), with values below -0.1 (representing a $10 \%$ luminescence reduction in relation to control) in $75 \%$ of the samples. Values of the toxicity index at 5 and $15 \mathrm{~min}$ had a good correlation in the dataset studied. 
TABle 3: Toxicity index of the water extract at $5 \mathrm{~min}$ (I5) and $15 \mathrm{~min}$ (I15). (M: mean; SD: standard deviation; a, b: significant differences $(P<.05)$ in Tukey test).

\begin{tabular}{cccccccccccccccc}
\hline & Sample & 1 & 2 & 3 & 4 & 5 & 6 & 7 & 8 & 9 & 10 & 11 \\
\hline \multirow{2}{*}{$\mathrm{I} 5$} & $\mathrm{M}$ & $-0.13 \mathrm{a}$ & $-0.01 \mathrm{~b}$ & $-0.07 \mathrm{~b}$ & $-0.21 \mathrm{a}$ & $0.10 \mathrm{~b}$ & $0.05 \mathrm{~b}$ & $0.04 \mathrm{~b}$ & $-0.03 \mathrm{~b}$ & $0.01 \mathrm{~b}$ & $-0.03 \mathrm{~b}$ & $-0.14 \mathrm{a}$ & $0.08 \mathrm{~b}$ \\
& $\mathrm{SD}$ & 0.02 & 0.07 & 0.08 & 0.05 & 0.10 & 0.03 & 0.02 & 0.01 & 0.08 & 0.03 & 0.03 & 0.10 \\
& $\mathrm{M}$ & $-0.15 \mathrm{a}$ & $-0.02 \mathrm{~b}$ & $-0.09 \mathrm{~b}$ & $-0.19 \mathrm{a}$ & $0.08 \mathrm{~b}$ & $0.08 \mathrm{~b}$ & $-0.03 \mathrm{~b}$ & $-0.06 \mathrm{~b}$ & $0.00 \mathrm{~b}$ & $-0.04 \mathrm{~b}$ & $-0.15 \mathrm{a}$ & $-0.01 \mathrm{~b}$ \\
$\mathrm{I} 15$ & $\mathrm{M}$ & 0.02 & 0.09 & 0.05 & 0.03 & 0.09 & 0.05 & 0.02 & 0.04 & 0.08 & 0.05 & 0.01 & 0.05 \\
& $S D$ & & & &
\end{tabular}

In the case of the sediments coming from the non-peridotite area or from a mixture of different parent materials (samples $5,6,7$, and 12), the toxicity index had values higher than zero, indicating the occurrence of hormesis phenomena related to the stimulation of the bacterial activity. Only one sample (4) had values of the toxicity index close to -0.25 (representing a 25\% reduction in luminescence with respect to the control), indicating a moderate degree of toxicity. The ANOVA of the toxicity index indicated that samples 1,4 , and 11 (located in the lower part of the peridotite area) significantly differed in relation to the other samples analysed (Table 3 ), with a toxicity index ranging from -0.13 to -0.21 ; therefore, these three samples had a luminescence reduction of more than $10 \%$ but less than $25 \%$, which could be related to the heavy-metal concentrations in the water extracts used in the bioassay. To correlate the heavy metal concentration in the water extracts with the toxicity index based on the reduction of luminescence, we used the Spearman correlation coefficient. In the studied dataset, we found a negative and significant correlation $(P<.05)$ between the toxicity index and the $\mathrm{Ni}$ and $\mathrm{Cr}$ concentration in the solutions. For I5, the coefficients were -0.636 with $\mathrm{Ni}$ and -0.622 with $\mathrm{Cr}$, and for I15 the coefficients were -0.650 with $\mathrm{Ni}$ and -0.580 with $\mathrm{Cr}$. The comparison with the toxic levels in the literature [27] indicates that the only elements exceeding these limits were $\mathrm{Ni}$ and $\mathrm{Cr}$, for which the toxic levels in water solutions surpassed 3- and 10fold, respectively. No significant correlations were detected for other heavy metals in the water extract, indicating the influence of the peridotite materials in the toxicity of the samples analysed.

\section{Conclusions}

The study area is dominated by peridotite materials, and the riverbed sediments in the basin have high concentrations of $\mathrm{Ni}, \mathrm{Mn}, \mathrm{Cr}$, and Co. The soluble forms were from the water extract of the sediments of the main river and tributaries in the basin. The toxicity bioassay with Vibrio fischeri used the water extract of these sediments to assess the bioluminescence reduction in these bacteria. The toxicity degree was very low in $75 \%$ of the samples, with values of luminescence reduction below $10 \%$ in relation to the control. A moderate-to-low degree of toxicity was found in $25 \%$ of the samples (all belonging to the non-peridotite area), with a luminescence reduction between 13 and $21 \%$ in relation to the control. The correlation coefficient (Spearman) indicated a negative and significant relation between the toxicity index and the concentrations in $\mathrm{Ni}$ and $\mathrm{Cr}$ in the water extracts of the sediments. This toxicity bioassay was proved to be a sensitive and useful tool for detecting the potential toxicity of solutions, even in samples with anomalous concentrations in heavy metals of natural origin.

\section{Acknowledgments}

The authors express their gratitude to the Regional Government of Andalusia (Spain), for supporting this study (Project RNM-03315). Also, they thank David Nesbitt for correcting the English version of the paper.

\section{References}

[1] M. Rutgers, J. Faber, and J. Postma, "Site-specific ecological risks- - basic approach to function-specific assessment of soil pollution," Tech. Rep. 16, Netherlands Integrated Soil Research Programme Reports, Wageningen, The Netherlands, 2001, English version no. 28.

[2] J. Jensen and M. B. Pedersen, "Ecological risk assessment of contaminated soil," Reviews of Environmental Contamination and Toxicology, vol. 186, pp. 73-105, 2006.

[3] S. C. Sheppard, C. Gaudet, M. I. Sheppard, P. M. Cureton, and M. P. Wong, "The development of assessment and remediation guidelines for contaminated soils, a review of the science," Canadian Journal of Soil Science, vol. 72, no. 4, pp. 359-394, 1992.

[4] J. Tarradellas, G. Bitton, and D. Rossel, Soil Ecotoxicology, Lewis, Boca Ratón, Fla, USA, 2000.

[5] A. E. Boekhold, "Ecological risk assessment in legislation on contaminated soil in The Netherlands," Science of the Total Environment, vol. 406, no. 3, pp. 518-522, 2008.

[6] D. J. L. Thomas, S. F. Tyrrel, R. Smith, and S. Farrow, "Bioassays for the evaluation of landfill leachate toxicity," Journal of Toxicology and Environmental Health B, vol. 12, no. 1, pp. 83-105, 2009.

[7] J. V. Tarazona, M. D. Fernández, and M. M. Vega, "Regulation of contaminated soils in Spain. A new legal instrument," Journal of Soils and Sediments, vol. 5, no. 2, pp. 121-124, 2005.

[8] M. Farré and D. Barceló, "Toxicity testing of wastewater and sewage sludge by biosensors, bioassays and chemical analysis," Trends in Analytical Chemistry, vol. 22, no. 5, pp. 299-310, 2003.

[9] S. Girotti, E. N. Ferri, M. G. Fumo, and E. Maiolini, "Monitoring of environmental pollutants by bioluminescent bacteria," Analytica Chimica Acta, vol. 608, no. 1, pp. 2-29, 2008.

[10] US EPA (United States Environmental Protection Agency), "Methods for assessing the toxicity of sediment-associated contaminants with estuarine and marine amphipods," Tech. 
Rep. EPA/600/R-94/025, United States Environmental Protection Agency, Washington, DC, USA, 1994.

[11] S. Parvez, C. Venkataraman, and S. Mukherji, "A review on advantages of implementing luminescence inhibition test (Vibrio fischeri) for acute toxicity prediction of chemicals," Environment International, vol. 32, no. 2, pp. 265-268, 2006.

[12] F. Martín, M. Diez, M. Simón, C. Dorronsoro, and I. García, "Soil contamination: from large to small scale," in Soil Contamination: New Research, pp. 35-45, Nova Science, Hauppauge, NY, USA, 2008.

[13] J.-F. Peng, Y.-H. Song, P. Yuan, X.-Y. Cui, and G.-L. Qiu, "The remediation of heavy metals contaminated sediment," Journal of Hazardous Materials, vol. 161, no. 2-3, pp. 633-640, 2009.

[14] C. K. Jain, "Metal fractionation study on bed sediments of River Yamuna, India," Water Research, vol. 38, no. 3, pp. 569578, 2004.

[15] W. Salomons and W. M. Stigliani, "Biogeodynamics of pollutants in soils and sediments: risk assessment of delayed and non-linear responses," in Environmental Science, pp. 331343, Springer, New York, NY, USA, 1995.

[16] W. Salomons and U. Förstner, "Trace metal analysis on polluted sediments. Part II: evaluation of environmental impact," Environmental Technology Letters, vol. 1, no. 11, pp. 506-517, 1980.

[17] J. Morillo, J. Usero, and I. Gracia, "Partitioning of metals in sediments from the Odiel River (Spain)," Environment International, vol. 28, no. 4, pp. 263-271, 2002.

[18] K. P. Singh, D. Mohan, V. K. Singh, and A. Malik, "Studies on distribution and fractionation of heavy metals in Gomti river sediments - a tributary of the Ganges, India," Journal of Hydrology, vol. 312, no. 1-4, pp. 14-27, 2005.

[19] S. Olivares-Rieumont, D. De La Rosa, L. Lima et al., "Assessment of heavy metal levels in Almendares River sedimentsHavana City, Cuba," Water Research, vol. 39, no. 16, pp. 39453953, 2005.

[20] U. Kraus and J. Wiegand, "Long-term effects of the Aznalcóllar mine spill-heavy metal content and mobility in soils and sediments of the Guadiamar river valley (SW Spain)," Science of the Total Environment, vol. 367, no. 2-3, pp. 855-871, 2006.

[21] A. V. Filgueiras, I. Lavilla, and C. Bendicho, "Evaluation of distribution, mobility and binding behaviour of heavy metals in surficial sediments of Louro River (Galicia, Spain) using chemometric analysis: a case study," Science of the Total Environment, vol. 330, no. 1-3, pp. 115-129, 2004.

[22] F. G. Viets Jr., "Chemistry and availability of micronutrients in soils," Journal of Agricultural and Food Chemistry, vol. 10, no. 3, pp. 174-178, 1962.

[23] G. Sposito, L. J. Lund, and A. C. Chang, "Trace metal chemistry in arid-zone field soils attended with sewage sludge. $\mathrm{I}$ : fractionation of $\mathrm{Ni}, \mathrm{Cu}, \mathrm{Zn}, \mathrm{Cd}$ and $\mathrm{Pb}$ in soils phases," Soil Science Society of America Journal, vol. 46, pp. 260-264, 1982.

[24] AZUR Environmental, "The Microtox® Acute Basic, DIN, ISO and Wet Test Procedure," Carlsbad, Calif, USA, 1998.

[25] J. Aguilar, C. Dorronsoro, E. Galán, and J. L. Gómez, "Criterios y estándares para declarar un suelo como contaminado en Andalucía," in Investigación y Desarrollo Medioambiental en Andalucía, pp. 45-59, University of Sevilla, Sevilla, Spain, 1999.

[26] F. Onorati and M. Mecozzi, "Effects of two diluents in the Microtox $\mathbb{R}$ toxicity bioassay with marine sediments," Chemosphere, vol. 54, no. 5, pp. 679-687, 2004.

[27] M. L. Bohn, B. L. McNeal, and G. A. O'Connor, Soil Chemistry, Wiley Interscience, New York, NY, USA, 1985. 

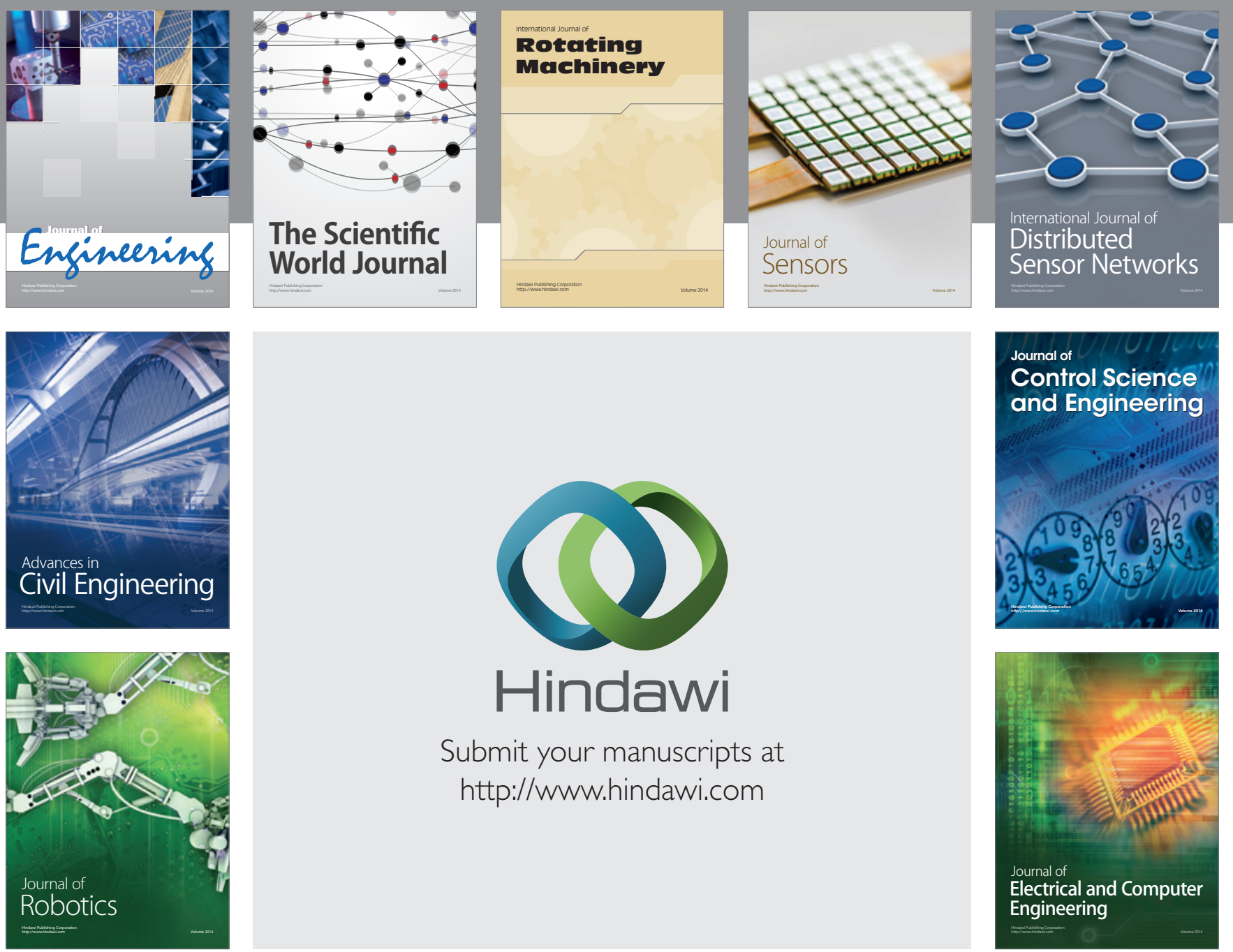

Submit your manuscripts at

http://www.hindawi.com
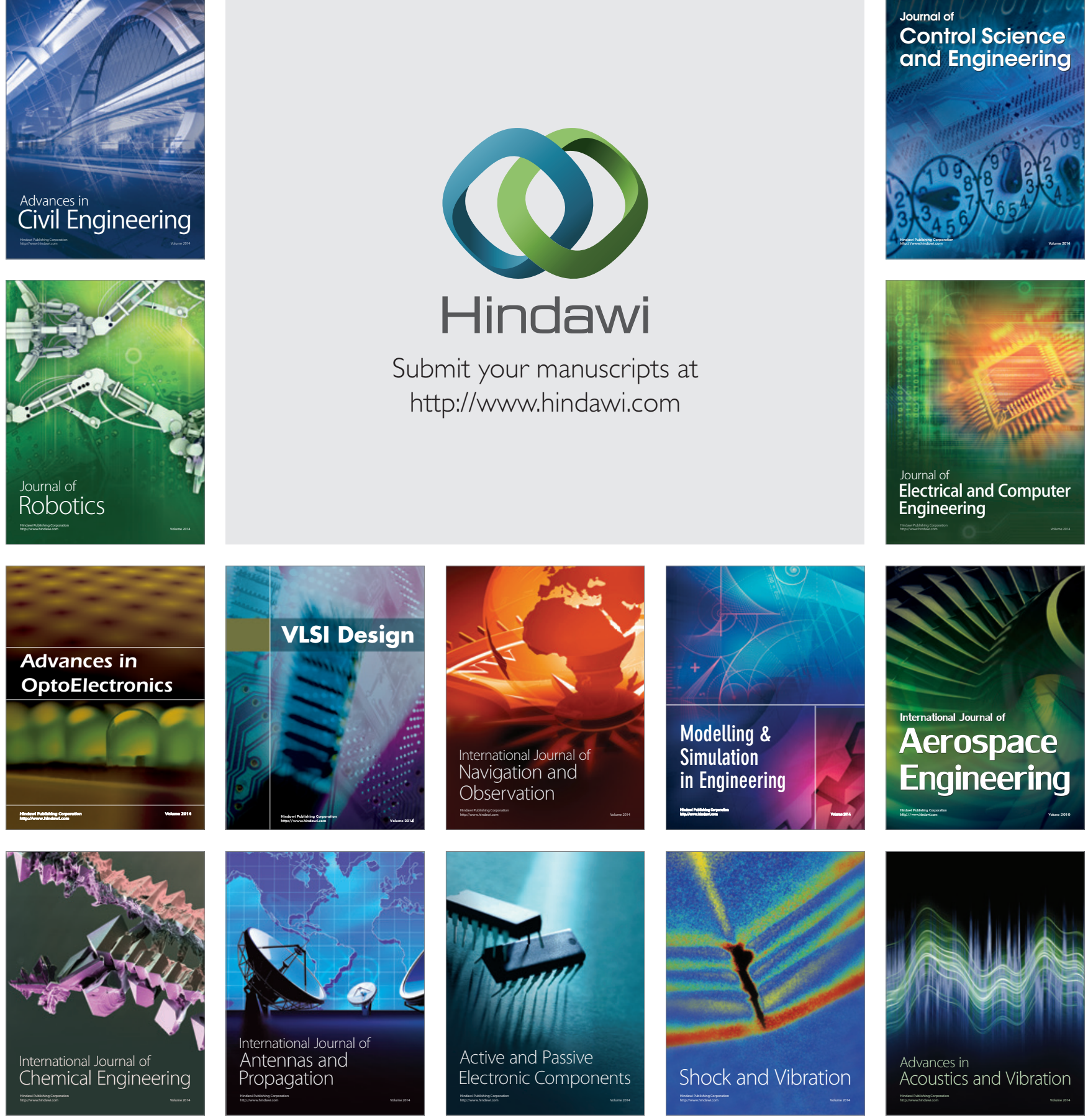